Thorax (1968), 23, 271.

\title{
Allergic alveolitis in a maltworker
}

\author{
H. F. V. RIDDLE, SONIA CHANNELL, W. BLYTH, D. M. WEIR, \\ MELODY LLOYD, W. M. G. AMOS, AND I. W. B. GRANT ${ }^{1}$
}

From the Departments of Respiratory Diseases, Botany, and Bacteriology, University of Edinburgh

\begin{abstract}
A further example of diffuse pulmonary hypersensitivity to an inhaled organic antigen is reported. A 42-year-old maltworker, who developed an illness resembling farmer's lung, was found to have been heavily exposed to the spores of Aspergillus clavatus. Precipitating and complement-fixing antibodies against an extract of $\boldsymbol{A}$. clavatus were detected in his serum, a late (Arthus-type) reaction was produced by intradermal injection of the same extract, and a pyrexial reaction, accompanied by a reduction in forced vital capacity and carbon monoxide transfer factor, occurred 6 hours after the inhalation of spores of $A$. clavatus. Two of the patient's four workmates complained of similar but less severe symptoms, and their sera also contained specific antibodies. Although the spores of $\boldsymbol{A}$. clavatus and of Cryptostroma corticale, the fungus responsible for maple-bark disease, are much larger than the $1 \mu$ spores of Micropolyspora sp., they may give rise to a diffuse pulmonary hypersensitivity reaction indistinguishable from that observed in farmer's lung. This suggests that the occurrence of such a reaction is not necessarily related to the size of the inhaled particles, and there is reason to believe that the concentration of spores or other antigenic particles in the inspired air may in this respect be more important than their size. The pulmonary hypersensitivity in this group of disorders appears to be a precipitin-mediated (type III) response to a variety of inhaled antigens, but some of these antigens may in certain patients, presumably atopic individuals, also provoke a reagin-mediated (type I) bronchial hypersensitivity reaction. It is suggested that a term such as 'allergic alveolitis' or 'extrinsic allergic alveolitis' may suitably be used to describe the group of diseases caused by pulmonary hypersensitivity to inhaled organic antigens.
\end{abstract}

Six examples of pulmonary hypersensitivity to inhaled organic antigens, confirmed by the detection of precipitating antibodies in the serum, have been reported since 1962 . These conditions appear to affect the peripheral gas-exchanging tissues of the lung, and are characterized by dyspnoea some hours after exposure, crepitations, diffuse micronodular opacities on radiological examination, and reduction in both vital capacity and carbon monoxide transfer factor. In most instances there is no clinical or physiological evidence of an obstructive disease of the airways, such as wheezing, or a reduction in the ratio of the forced expiratory volume in one second (F.E.V.1.0) to the forced vital capacity (F.V.C.).

The first of these disorders to be recognized as such was farmer's lung, in which Pepys, Riddell, Citron, and Clayton (1962) demonstrated precipitating antibodies against antigens derived from mouldy hay in the serum of patients with this

\footnotetext{
1 Requests for reprints should be addressed to Dr. I. W. B. Grant, Respiratory Diseases Unit, Northern General Hospital, Ferry Road, Edinburgh, 5
}

condition, and later identified Micropolyspora sp. (Thermopolyspora polyspora) as the chief source of antigen (Pepys, Jenkins, Festenstein, Gregory, Lacey, and Skinner, 1963). Other workers subsequently demonstrated precipitins against other antigens in bird fancier's lung (Reed, Sosman, and Barbee, 1965 ; Hargreave, Pepys, Longbottom, and Wraith, 1966), in bagassosis (Salvaggio, Buechner, Seabury, and Arquembourg, 1966), in maple-bark disease (Emanuel, Wenzel, and Lawton, 1966), in patients inhaling pituitary snuff (Pepys, Jenkins, Lachmann, and Mahon, 1966), and in a laboratory worker handling the grain weevil (Lunn and Hughes, 1967).

A further example of a similar type of pulmonary hypersensitivity occurring in a maltworker exposed to the spores of Aspergillus clavatus is described in this paper.

\section{CASE REPORT}

CLINICAL HISTORY A 42-year-old maltsman (W. G.) with no important previous history of respiratory 
disease presented to his general practitioner in November 1966 complaining of progressive exertional dyspnoea, cough, mucoid sputum, and night sweats. These symptoms subsided completely after he had stopped work for a week, during which time he was treated with tetracycline. A few hours after he returned to work, the dyspnoea and cough recurred, and during the night he felt hot and feverish. He was off work on this occasion for two weeks, and once more made a complete recovery, but on the evening of the day on which he resumed work he had a further recurrence of the same symptoms.

When he was referred to the Northern General Hospital, Edinburgh, on 22 December 1966 he was short of breath on mild exertion but was afebrile. Coarse crepitations, but no rhonchi, were audible over both lungs, and a postero-anterior chest radiograph (Fig. 1) showed diffuse bilateral micronodular shadowing. The F.V.C. was 3.74 1. (predicted normal = 4.20 1.) and the F.E.V.1.0 was 2.46 1. (predicted normal $=3.36$ 1.). The total white-cell count was 10,500 per cu.mm., with a normal differential count. The sputum was mucoid, and on bacteriological examination only a normal upper respiratory commensal flora was found. Mycological examination, however, yielded a mixed growth of $A$. clavatus, Penicillium brefeldianum, and Rhizopus sp., with a single colony of Aspergillus fumigatus.

When his condition was reviewed on 29 December 1966 his symptoms had improved slightly, and the F.V.C. and F.E.V.1.0 had increased to 4.151 . and 2.70 1. respectively. The radiological appearances were, however, unchanged and for this reason it was decided to treat him with prednisolone, which was given in a dose of $20 \mathrm{mg}$. per day for 14 days and was gradually withdrawn during the next 14 days. When treatment was stopped on 26 January 1967 he was asymptomatic, and clinical examination was negative. His F.V.C. and F.E.V.1.0 had risen to $4.95 \mathrm{l}$. and 3.401 . respectively, and the radiological appearances had returned virtually to normal. The total white-cell count was 5,100 per cu.mm. with no increase in eosinophils, and the erythrocyte sedimentation rate was $11 \mathrm{~mm}$. in the first hour.

He was admitted to hospital on three occasions during February 1967 for further investigations, including inhalation provocation tests. There was a temporary relapse in his condition after the second of these tests (reported below), but a week later he had recovered completely. He returned to work at the maltings in March 1967 but was not sent back to the open malt floors. Initially, he was given duties in a separate building, where there was no dust hazard, but a few weeks later he was employed as a greaser and was again exposed for short periods to dust emanating from the malt floors where he had worked originally. This was soon followed by a recurrence of dyspnoea and a fall in F.V.C. and F.E.V.1.0 to 4.20 1. and 2.901 . respectively. Because of this development he decided to terminate his employment at the maltings, and when his condition was reviewed five weeks later he was clinically well, his chest radiograph was normal, and his F.V.C. and F.E.V.1.0 were 4.801 . and $\overrightarrow{\vec{\omega}}$ 3.20 1. respectively.

Four other men were working on the same malt $\frac{0}{\square}$ floor when the patient developed his initial symptoms. $\frac{\overline{\bar{O}}}{\bar{\rho}}$ All had normal chest radiographs, but two of them $\frac{\mathrm{S}}{7}$ complained of shortness of breath after returning $\Omega$ home at the end of a day's work. A limited series of investigations were undertaken on these men, and $s$ the results are reported later in this paper.

OCCUPATIONAL HISTORY Until February 1966 the $\overrightarrow{\vec{\omega}}$ patient had worked in a paper-mill, but he then changed his occupation to work in an open floor $\vec{x}$ maltings. The various steps in the malting process, in which he was engaged, are shown in Figure 2. Barley $\omega$ from the farms, after being dried in kilns, is stored is for at least eight weeks in silos. It is then rehydrated $\underset{I}{ }$ by steeping in tanks, several changes of water being 음 made over 36 hours and hypochlorite solution being added as a fungicide. The barley is then allowed to $\vec{z}$ germinate on open floors, the rate of germination being controlled by regulation of the temperature and humidity. This is done by thickening or thinning the $\vec{\theta}$ layer of malt. The malt is also turned regularly to $\infty$ release carbon dioxide and to aerate the grain. The floor temperature is traditionally kept at about $18^{\circ} \mathrm{O}$ C. The malt is then dried in kilns, and the temperature is raised slowly to $82^{\circ} \mathrm{C}$., after which it is screened once again to remove the rootlets (known as 'culms'). Finally, the finished malt is transferred to $\stackrel{\unrhd}{\varrho}$ the distillery. All the waste products go to provender $\overrightarrow{\vec{A}}$ merchants for conversion to cattle foods.

The patient helped with all the processes described above, but his main work was to turn the malt on the open floors with a machine. This normally produces very little dust, but the onset of the patient's symptoms was noticed to coincide with the observation that음 a heavy green dust was rising from the malt while it was being turned. This dust was so dense that ito reduced visibility across the malting floor, and the 3 . men started to wear gamgee face masks, normally reserved for kiln working. The contamination of these 3 masks was so great that it was found necessary to 0 double the thickness of the gamgee and to change it two or three times daily.

The green dust had first been observed when malting of the new season's grain was started in Octobern 1966. This was known to contain a larger numberof split corns than normal. The local farmers were? growing a new type of barley, with a higher yieldn but thinner skin than the traditional types. In wet ${ }_{\sigma}$ summers, such as 1966, the grain in the field tends to swell, and many of the corns are split. Such splif corns are particularly prone to infection by fungi. Furthermore, the temperature of the malt floors had; since the beginning of the 1966-7 malting season, been kept at $24^{\circ} \mathrm{C}$. $\left(6^{\circ}\right.$ higher than the traditional value) by spraying the malt with water on the second day? The purpose of this was to reduce the duration of the malting process from 10 to 6 days, and so to increase the overall production of malt, with obvious economic advantages but at the risk, not realized af 
(b)

FIG. 1. (a) Postero-anterior chest radiograph taken during acute phase of illness. (b) Detail of right lower zone.

the time, of increasing the amount of fungal growth on the germinating barley.

Samples from the maltings, including unprocessed barley, germinating barley, culms, dust, and face masks, were submitted to mycological examination, and a profuse growth of $A$. clavatus was obtained from almost every specimen. Two other fungi, $\boldsymbol{P}$. brefeldianum and Rhizopus sp., which had been isolated from the patient's sputum, were also cultured from some of the samples. Fungi are common grain contaminants on open malt floors, but $A$. clavatus was not cultured from samples obtained from two other maltings in the same district.

\section{SPECIAL INVESTIGATIONS}

Inhalational provocation tests These were performed with $(a)$ an aqueous extract of spores of $A$. clavatus, (b) dry spores of $\boldsymbol{A}$. clavatus, and (c) dry spores of $P$. brefeldianum. It proved technically impossible to prepare a fine dry powder, suitable for inhalation, with spores of Rhizopus sp., and the patient's sensitivity to this agent was therefore not tested. 


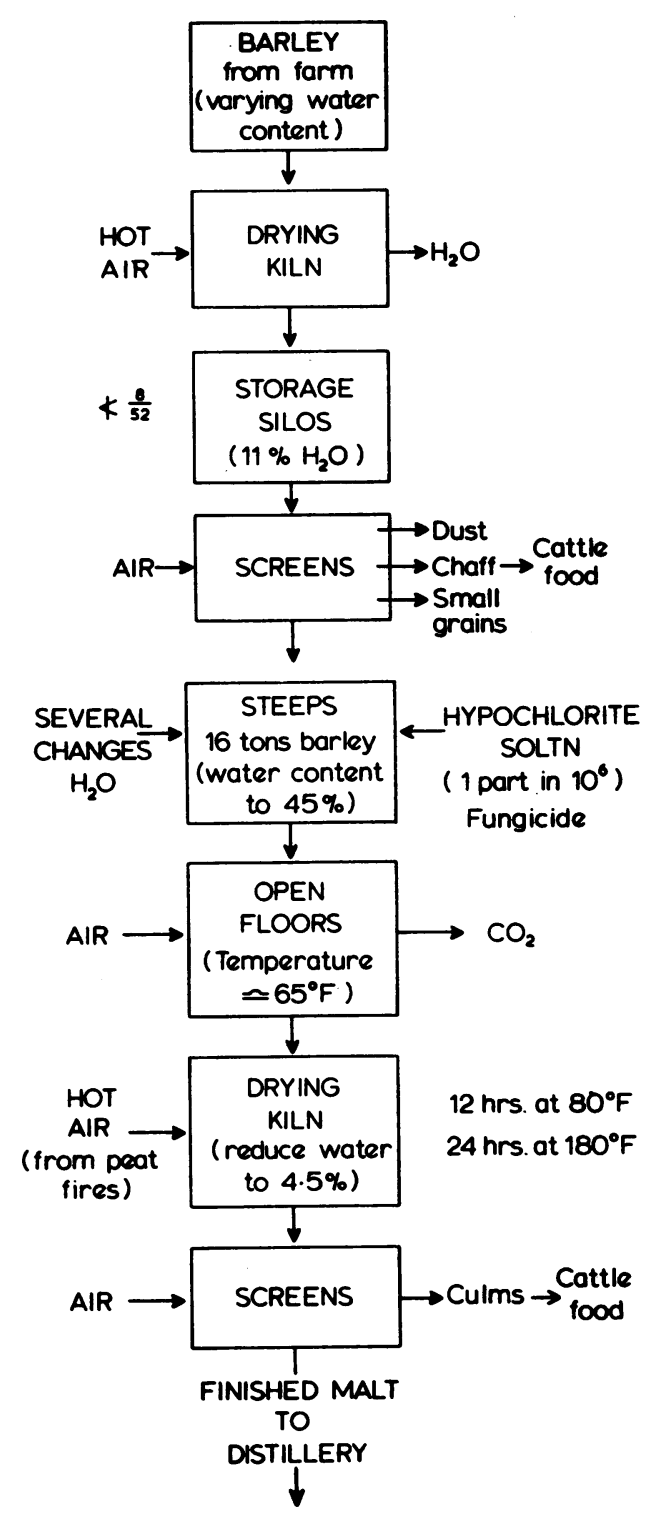

FIG. 2. Steps in the malting process.

The results were as follows:

(a) The inhalation of an extract of spores of $A$. clavatus, administered by a Wright-Smith nebulizer, produced no symptoms nor pyrexia, but the F.V.C. fell by 0.41 . eight hours later. It was subsequently shown, however, that variations in F.V.C. of this magnitude occurred in this patient during any normal day.

(b) The changes in F.V.C. and oral temperature following the inhalation of $20 \mathrm{mg}$. of dry spores of $A$. clavatus are shown in Figure 3. Three hours? after the inhalation the F.V.C. began to fall, and at seven hours it was more than 1 litre belowe the pre-inhalation level. His temperature begars to rise at six hours, and at eight hours had reache\& about $39^{\circ} \mathrm{C}$. The pyrexia did not subside untid 24 hours after the inhalation, and the F.V.C. re $=$ mained subnormal for a week. At the height of the reaction the patient complained of retrosternat tightness, shortness of breath, nausea, sweatingo headache, and generalized aching in the trunk and limbs. He volunteered the information that these symptoms were virtually identical with those he had experienced when he was at work. The results of respiratory function tests before and 24 hours after the inhalation are shown in Table I. It can be seen that there was a fall in $\mathrm{PaO}_{2}$ and

\section{T A B L E I}

CHANGES IN RESPIRATORY FUNCTION FOLLOWING INHALATION OF ASPERGILLUS CLAVATUS SPORES

\begin{tabular}{|c|c|c|c|c|c|}
\hline & & & & $\begin{array}{c}\text { Before } \\
\text { Inhalation }\end{array}$ & $\begin{array}{c}\text { After } \\
\text { Inhalation }\end{array}$ \\
\hline 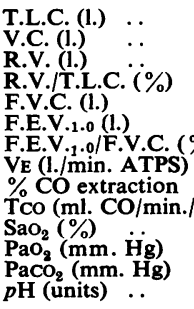 & $\begin{array}{l}\because \\
. \\
. \\
\cdots \\
\therefore \\
\% \\
\ldots \\
. \mathrm{mm} . \mathrm{F} \\
\ldots \\
\cdots \\
\cdots\end{array}$ & 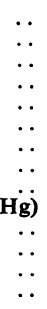 & $\begin{array}{l}\because \\
\because \\
\because \\
\therefore \\
\therefore \\
\because \\
\because \\
\because \\
\because \\
\because \\
\because\end{array}$ & $\begin{array}{c}7.82 \\
5.45 \\
2.37 \\
30 \\
5.45 \\
3.6 \\
66 \\
6.05 \\
46 \cdot 3 \\
10.3\end{array}$ & $\begin{array}{c}6 \cdot 35 \\
4 \cdot 05 \\
2 \cdot 3 \\
36 \\
4 \cdot 0 \\
2 \cdot 7 \\
67 \\
10 \cdot 5 \\
33 \cdot 5 \\
9 \cdot 4 \\
90 \\
56 \cdot 5 \\
23 \cdot 5 \\
7 \cdot 510\end{array}$ \\
\hline
\end{tabular}

in the value obtained for carbon monoxide trans fer factor. There was also a sharp increase i resting pulmonary ventilation, which produced fall in $\mathrm{PaCO}_{2}$ to $23.5 \mathrm{~mm}$. $\mathrm{Hg}$ and a respirator alkalosis. The haematological changes which followed inhalational provocation are shown io Table II. These consisted of an increase in the number of neutrophil polymorphs (without eosinos. philia) and a progressive elevation in the erythros cyte sedimentation rate, which was still continuing four days after the spores had been inhaled.

T A B L E II

HAEMATOLOGICAL CHANGES FOLLOWING INHALATIOA HAEMATOLOGICAL CHLLUS CLAVATUS SPORES

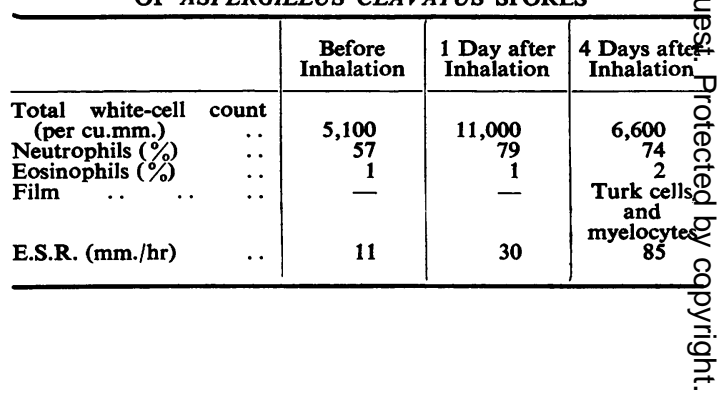




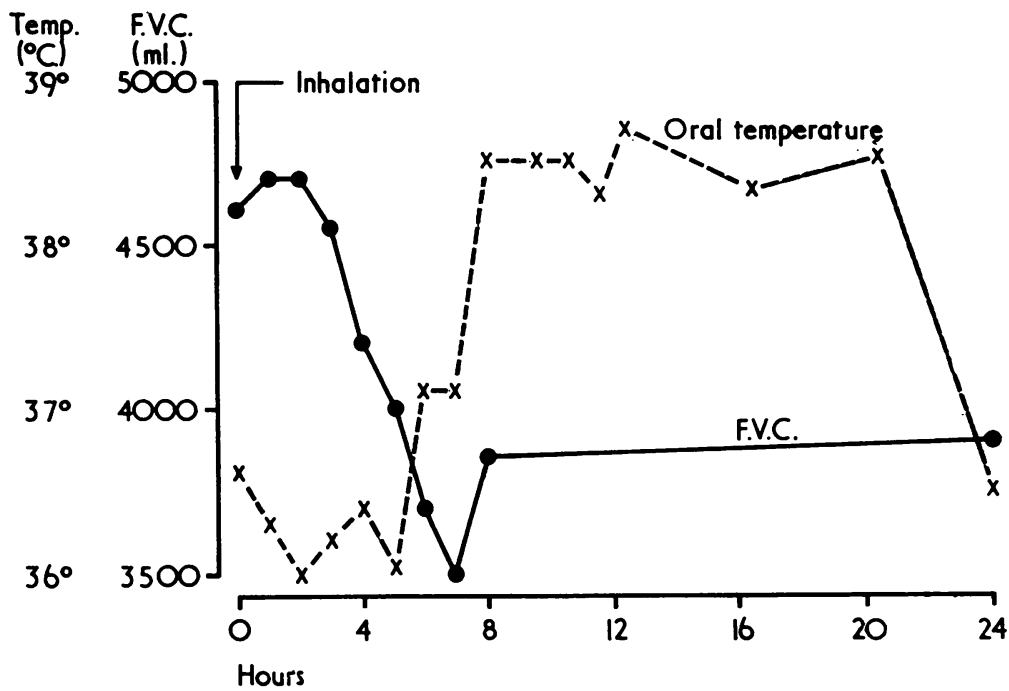

FIG. 3. Changes in forced vital capacity and oral temperature following the inhalation of spores of A. clavatus.

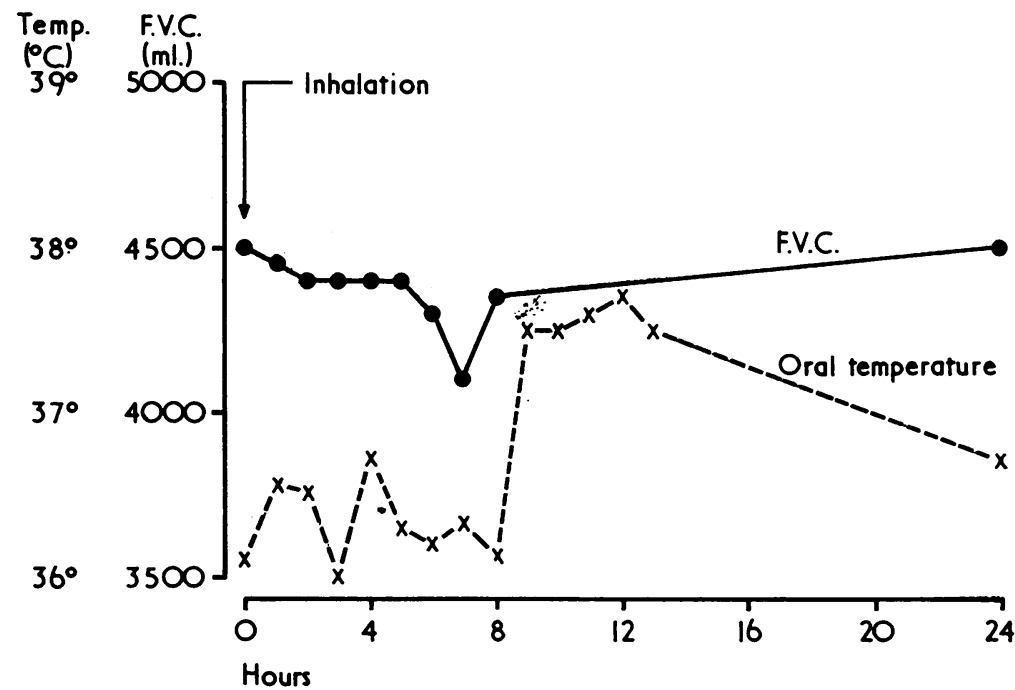

FIG. 4. Changes in forced vital capacity and oral temperature following the inhalation of spores of $\mathrm{P}$. brefeldianum.

(c) The changes in F.V.C. and oral temperature . following the inhalation of $20 \mathrm{mg}$. of spores of $P$. brefeldianum are shown in Figure 4. A slight increase in oral temperature was recorded eight hours after the inhalation, but there was no significant reduction in F.V.C.: the pyrexia may thus merely have represented a non-specific reaction to foreign protein, and such a phenomenon has in fact been reported in control subjects exposed to avian and mouldy hay extracts by Reed et al. (1965) and Barbee, Dickie, and Rankin (1965).

Immunological studies on serum and skin These are summarized in Table III. Each fungal antigen was prepared from the total extract of a threeweek culture, using a modification of the method described by Longbottom and Pepys (1964). For the gel diffusion tests, a double diffusion plate: 
T A B L E I I I RESULTS OF IMMUNOLOGICAL STUDIES ON PATIENT

\begin{tabular}{c|c|c|c|c|c}
\hline Antigen & $\begin{array}{c}\text { Gel } \\
\text { Dif- } \\
\text { fusion } \\
\text { Test }\end{array}$ & $\begin{array}{c}\text { Comple- } \\
\text { ment } \\
\text { Fixation } \\
\text { Test }\end{array}$ & $\begin{array}{c}\text { Intra- } \\
\text { dermal } \\
\text { Test (Late } \\
\text { Reaction) }\end{array}$ & $\begin{array}{c}\text { Prick } \\
\text { Test } \\
\text { Immediate } \\
\text { Reaction) }\end{array}$ & $\begin{array}{c}\text { Hist- } \\
\text { amine } \\
\text { Release } \\
\text { Test }\end{array}$ \\
\hline $\begin{array}{c}\text { F.L.H. } \\
\begin{array}{c}\text { Avian protein } \\
\text { Aspergillus } \\
\text { fumigatus }\end{array}\end{array}$ & - & - & - & - & - \\
\hline $\begin{array}{c}\text { Aspergillus } \\
\text { clavatus }\end{array}$ & + & + & + & - & - \\
\hline $\begin{array}{c}\text { Penicillium } \\
\text { brefeldianum }\end{array}$ & - & - & + & & \\
$\begin{array}{c}\text { Rhizopus } \\
\text { species }\end{array}$ & - & - & + & & \\
\hline
\end{tabular}

technique (Ouchterlony, 1949) was used. The complement fixation tests were performed on W.H.O. Perspex plates by a four-drop system, with anticomplementary control, using 1.25 MHD guinea-pig complement. The end-point was taken as the last tube showing clearly visible red cells after incubation at $4^{\circ} \mathrm{C}$. for 24 hours, followed by incubation for 40 minutes at $37^{\circ} \mathrm{C}$. after the addition of $3 \%$ sensitized sheep cells. Standard techniques were used for the prick and intradermal tests. In the histamine release test human lung tissue was passively sensitized by the patient's serum, and exposed to antigen. The amount of histamine released from the preparation was then assayed by a pharmacological method (Bukhari, 1967). There is some evidence to suggest that a positive test indicates the presence of reaginic antibody (Augustin, 1967).

The patient's serum did not contain precipitating antibodies against F.L.H. or avian protein antigens, or against antigens derived from $A$. fumigatus, $\boldsymbol{P}$. brefeldianum, or Rhizopus sp. The presence of precipitating antibodies to $A$. clavatus antigen was indicated by positive gel diffusion and complement fixation tests, and by a late (Arthustype) reaction to intradermal injection of antigen. The absence of reaginic antibody was indicated by a negative prick test and a negative histamine release test. Gel diffusion and complement fixation tests on sera from 36 controls (including normal subjects and asthmatics) were all negative. A late (Arthus-type) reaction was produced by the intradermal injection of extracts of both $P$. brefeldianum and Rhizopus sp., but these were less marked than the reaction to $A$. clavatus. Six normal controls showed no immediate or late reaction to the intradermal injection of any of the three extracts.

The results of serological tests on the patient's four workmates are shown in Table IV. Positive gel diffusion and complement fixation tests with $\overrightarrow{\overrightarrow{\mathrm{w}}}$ $A$. clavatus antigen were obtained in two of theseo subjects, and both showed a late (Arthus-type)음 skin reaction to an intradermal injection of the $\frac{\bar{c}}{}$ same antigen.

T A B L E IV

RESULTS OF SEROLOGICAL TESTS IN PATIENT'S FELLOWWORKERS

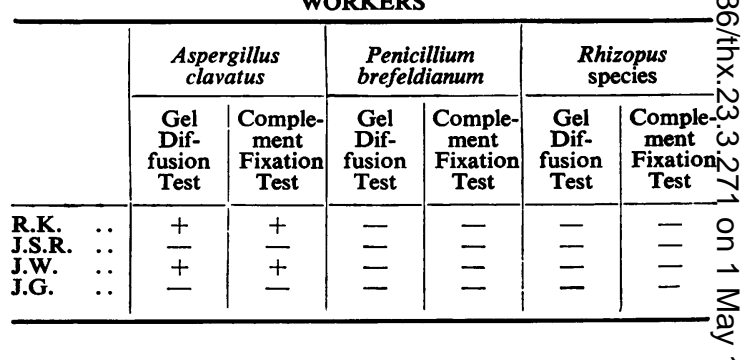

DISCUSSION

DIAGNOSIS The patient's illness was similar in all essential respects to that of farmer's lung. He gaved a characteristic history of symptoms developing late in the day after exposure to mouldy vegetable $\underset{\rightarrow}{\stackrel{2}{ }}$ material, and showed the typical clinical featureso of breathlessness, cough, malaise, and fever, asso- $\frac{}{5}$ ciated with the presence of crepitations on auscultation and a striking absence of wheeze. The radiological picture of micronodular shadowing, distributed throughout both lung fields, was also consistent with the diagnosis. The patient's serum, $\underset{-}{\stackrel{x}{-}}$ however, did not contain precipitating antibodies 3 . against F.L.H. antigens, and the temperature on the malt floor $\left(24^{\circ} \mathrm{C}\right.$.) was not in fact high enough to promote the growth of thermophilic actino-o mycetes. The negative gel diffusion test with avian antigen also virtually excluded a diagnosis of birdo fancier's lung. On the other hand, the patient was known to be exposed to vast numbers of spores of $N$ $A$. clavatus at his place of work, the same fungus N was cultured from his sputum, and there was an consistent time-relationship between each renewed ${ }_{\sigma}^{\omega}$ exposure to the spore-containing dust in the maltings and each recurrence of symptoms. There appeared to be strong $a$ priori grounds for attri- $-\infty$ buting the patient's illness to pulmonary hyper-? sensitivity to the spores of $\boldsymbol{A}$. clavatus.

Support for this hypothesis was provided by (1) the detection in the patient's serum of precipi- $\frac{\mathcal{P}}{\mathbb{O}}$ tating antibody against an antigen prepared from $\mathrm{\varrho}$ $A$. clavatus, but not against those prepared from other fungi in the patient's sputum and on the 
malt floors, (2) his response to the inhalation of spores of $\boldsymbol{A}$. clavatus, (3) the late (Arthus-type) reaction to an intradermal injection of $A$. clavatus extract, and (4) the finding of precipitating antibodies against $A$. clavatus in the serum of two of the patient's workmates, who also exhibited a late (Arthus-type) reaction after intradermal injection of the same extract.

It seemed unlikely that the other two fungi isolated both from the patient's sputum and from the malt floors, $P$. brefeldianum and Rhizopus sp., were of aetiological importance, as the patient's serum did not contain precipitating antibodies against antigens prepared from either of these fungi. On the other hand, the late (Arthus-type) skin reaction produced by the intradermal injection of extracts of $\boldsymbol{P}$. brefeldianum and $R$ hizopus sp. presumably indicated that the patient had been sensitized by these organisms, and the same interpretation could perhaps be placed on the slight reaction to the inhalation of spores of $P$. brefeldianum. Nevertheless, by all available criteria, the patient exhibited a more marked degree of sensitivity to $A$. clavatus than to either of the other two fungi, and we think that his illness was caused by the inhalation of spores of $A$. clavatus which provoked a type III hypersensitivity response, as defined by Gell and Coombs (1963).

MYCOLOGY OF ASPERGILLUS CLAVATUS This fungus is so named because of the club- or clavate-shaped heads of the vesicles, which carry a single series of sterigmata crowned by chains of smoothwalled oval spores, measuring $3.5 \times 2.5 \mu$ (Fig. 5). The scale diagram illustrates the large size of the vesicles, compared with those of other aspergilli associated with human disease. The various spores are also illustrated on a different scale.

A. clavatus is a common soil contaminant, often found in decomposing material of high nitrogen content and in animal dung. Like many other

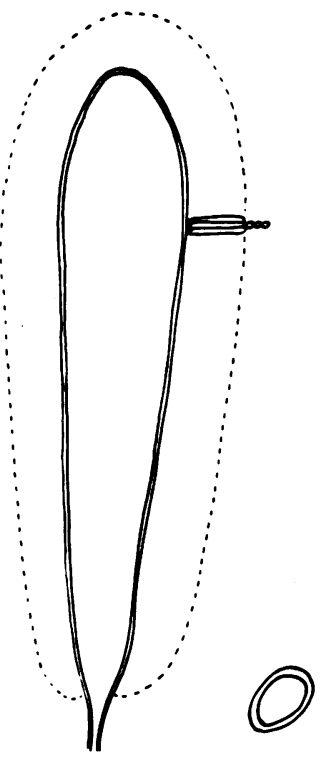

ASPERGILLUS CLAVATUS

Colony - blue-green with white mycelial mat

Conidiophore $1.5-3 \mathrm{~mm}$ in length

Conidial head-clavate $250 \mu \times 50 \mu$

Sterigmata in one series only

Conidia - elliptical smooth, thick walled

$3.5 \mu$ in length
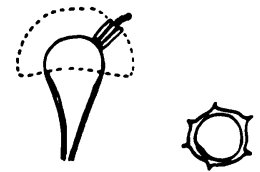

ASPERGILLUS FUMIGATUS
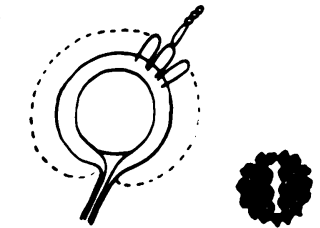

ASPERGILLUS NIGER
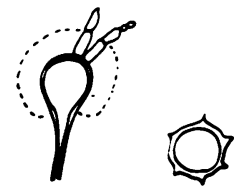

ASPERGILLUS VERSICOLOR

FIG. 5. Morphological features of A. clavatus and other aspergilli. 
fungi, it has been investigated in regard to its antibiotic-producing potential. Two potent substances have been extracted, clavicin and clavatin (these may be identical), and these have been reported to be of value in the treatment of the common cold (Raper and Fennell, 1965). An isolate of $A$. clavatus growing in mouldy feed pellets has been shown to produce hyperkeratosis in cattle, associated with lachrymation, depression, and haemorrhagic lesions in the liver (Forgacs, Carll, Herring, and Mahlandt, 1954), but in man the only disease so far attributed to $A$. clavatus is onychogryphosis (Batista, Maia, and Alecrum, 1955).

The occurrence of $A$. clavatus in the maltings where the patient worked appears to have been due to a variety of factors:

1. The malting of a new type of barley which, after a wet summer, contained large numbers of split corns.

2. The increased temperature and humidity on the malt floors, which was deliberately produced by spraying the grain with water on the second day of the malting process in order to accelerate enzymatic activity. This attempt to increase production, together with the use of barley with a high percentage of split corns, may have unwittingly provided the ideal conditions for an explosive outbreak of fungal contamination, as there is evidence (unpublished) available in the malting industry to indicate that an $80 \%$ increase in the rate of sporulation occurs when the temperature at which other aspergilli are cultured is raised from $14^{\circ} \mathrm{C}$. to $20^{\circ} \mathrm{C}$.

3. The use of dilute hypochlorite to reduce such contamination of the rehydrated barley may in fact have had the opposite effect to that intended, as it has been shown by one of the authors (M. L.) that the growth of $A$. clavatus is potentiated by the addition of this alkaline agent to culture media.

The primary source of the contamination is still in doubt, but it may be relevant that $A$. clavatus was cultured from pigeon droppings collected from several roostings about the maltings, and that the site of heaviest contamination was around the windows of an open grain store, through which the pigeons had free access. Every part of the malt floors was, however, so heavily infected that the role of the pigeons in the maintenance of fungal contamination must have been relatively unimportant.

PATHOGENESIS Histological studies of the pulmonary lesions in farmer's lung (Dickie and Rankin,
1958 ; Totten, Reid, Davis, and Moran, 1958 ; $\overrightarrow{\vec{A}}$ Frank, 1958 ; Riddell and Stewart, 1958 ; and Seal, $\stackrel{\circ}{\circ}$ Thomas, and Griffiths, 1963) have shown that in the acute stage the most constant finding is an interstitial pneumonitis, with thickening of the $\overrightarrow{\widetilde{D}}$ alveolar walls and a mononuclear infiltrate. These $\varrho$ reports are consistent with the hypothesis that the pulmonary changes are in this condition the result $\vec{\circ}$ of an antigen-antibody reaction in the alveolarwalls. There was only indirect serological evidence $\vec{\rho}$ (Pepys et al., 1963) of a causal relationship between the suspected aetiological agent and the $x$ histological lesions until Wenzel, Emanuel, Lawton, and Magnin (1964) isolated Micropolysporaiv sp. from a lung biopsy. Since the spores of this $N$ organism are very small ( $1 \mu$ in diameter) and can $\vec{\circ}$ readily penetrate to the alveoli, the theory was advanced that all type III hypersensitivity reac- $\vec{\sim}$ tions were caused by fine organic dusts of equally small particle size (Pepys et al., 1963 ; Pepys, $\rightarrow$ Longbottom, and Jenkins, 1964; and Pepys, 1967a). This theory carried the implication that? larger organic particles would be trapped on the bronchial mucosa, and would not reach the alveolis in sufficient numbers to produce a similar type of reaction there. The evidence in favour of this view is, however, by no means conclusive. On ${ }_{\mathscr{Q}}^{\mathbb{\Phi}}$ theoretical grounds, Findeisen (1935), supported $\stackrel{-}{=}$ experimentally by Brown, Cook, Ney, and Hatch (1950), has shown that although 40 to $60 \%$ of particles of $1 \mu$ size can penetrate to the alveolip? as many as 15 to $20 \%$ of particles of $5 \mu$ size can also reach the alveoli, and, of more significance, a. very large proportion of these are retained $\underset{x}{\tilde{D}}$ Gregory and Lacey (1963) made similar predictionso about the penetration of spores of $5 \mu$ diameter when they investigated the spores produced in mouldy hay. More recently, Booker, Chamberlain? Rundo, Muir, and Thomson (1967) have cons firmed that not only are $5 \mu$ particles able to reach the alveoli, but they are retained in decreasing numbers for up to 300 days. It has now been shown, in the case reported in this paper, that the inhalation of the larger spores of $A$. clavatus car reproduce the clinical and other features of syndrome identical with that of farmer's lungo Furthermore, Emanuel et al. (1966) have reported another example of this syndrome in maple-barl strippers, following exposure to the spores of Cryptostroma corticale, which are even larger (5 $\times 3 \mu$ ) than those of $A$. clavatus. On the basis of these observations it is no longer possible to sus@ tain the view that a difference in the size og individual spores is the factor which determines whether a hypersensitivity response caused by the 
inhalation of spores occurs predominantly in the bronchial mucosa or in the alveolar walls. It is possible that some degree of 'clustering' of inhaled spores may occur, more marked in some species than in others, and that this could explain why a hypersensitivity reaction to the inhalation of spores of $\boldsymbol{A}$. fumigatus is predominantly bronchial, while in the case of $A$. clavatus, Micropolyspora sp., and $C$. corticale it is predominantly pulmonary. It has, however, been shown by one of the authors (M. L.) that the spores of $A$. fumigatus and of $A$. clavatus do not differ significantly in their tendency to aggregate and form 'clusters'.

A study of the many published case histories shows that a feature common to all pulmonary hypersensitivity reactions of the farmer's lung type is exposure to antigen-containing dust in very high concentrations. Until recently, there was no recorded instance of an individual having been exposed to comparable concentrations of $\boldsymbol{A}$. fumigatus spores, but a paper published in Czechoslovakia (Filip and Barbořík, 1966) describes the effects on one man and 17 women of exposure to an atmosphere containing vast numbers of such spores. Although we do not agree with the authors' conclusions, the case histories, as they were presented, leave us in little doubt that the individuals were in fact suffering from a farmer's lung type of syndrome. If this evidence is accepted, $\boldsymbol{A}$. fumigatus can be added to the list of antigens which, when inhaled in a sufficiently high concentration, are capable of inducing a diffuse type III (precipitin-mediated) hypersensitivity reaction in the lungs. A fumigatus is, of course, known for its role in the production of pulmonary eosinophilia (Longbottom and Pepys, 1964), in which immunological evidence for both a type I and a type III response, as defined by Gell and Coombs (1963), is frequently found. The asthmatic features in this condition are presumably related to the type I (reagin-mediated) response, while the transient pulmonary infiltrates may represent a local type III response to fungal mycelium contained in bronchial mucus plugs (Turner-Warwick and Pepys, 1967).

Some of the antigens responsible for diffuse pulmonary hypersensitivity (type III) also provoke, presumably in atopic individuals, a type I (bronchial) response. This gives rise to reversible airways obstruction, an excess of eosinophil leucocytes in the peripheral blood and in the sputum, and an immediate skin reaction to a prick test with the suspected antigen. Such a combination of type I (bronchial) and type III (pulmonary) hypersensitivity has been reported in patients exposed to avian antigens, pituitary snuff, and the grain weevil (Hargreave et al., 1966; Mahon, Scott, Ansell, Manson, and Fraser, 1967 ; and Lunn and Hughes, 1967).

It is probable that the number of cases so far reported of diffuse pulmonary hypersensitivity to inhaled organic antigens represents only a minute fraction of the total incidence of the disorder. There must be many undiagnosed cases belonging to the groups already identified, and there may be an even larger number of patients with diffuse pulmonary lesions caused by hypersensitivity to as yet unrecognized organic antigens. One of the authors (I. W. B. G.), in a paper delivered to the Thoracic Society in July 1967, suggested that the generic term 'allergic alveolitis' might be applied to pulmonary disease of this type ; Pepys, quoted in a British Medical Journal leader (1967b), preferred the term 'extrinsic allergic alveolitis'. To pathologists both terms may be unacceptable on the grounds that the histological features of the pulmonary lesions are not pathognomonic of an allergic response, but for the present either term will serve as a convenient, and perhaps not entirely misleading, label for a well-defined condition with readily identifiable clinical, radiological, and immunological features.

This research programme has been supported by a grant from the Scottish Hospitals Endowments Research Trust.

Our thanks are due to Miss L. M. Tully and Miss S. Merchant for undertaking the physiological investigations, to Dr. G. J. R. McHardy for his comments on the findings, and to Mr. W. Paul for carrying out the histamine release tests on sensitized lung. We are also indebted to Miss L. Black and Miss J. Holywell for efficient secretarial assistance.

\section{REFERENCES}

Augustin, R. (1967). Demonstration of reagins in the serum of allergic subjects. Handbook of Experimental Immunology. Ed. Weir, D. M. p. 1076. Blackwell, Oxford and London.

Barbee, R. A., Dickie, H. A., and Rankin, J. (1965). Pathogenicity of specific glycopeptide antigen in farmer's lung. Proc. Soc. exp. Biol. (N.Y.), 118, 546.

Batista, A. C., Maia, H. da S., and Alecrum, I. da C. (1955). Onicomicose produzida por 'Aspergillus clavato-nanico' n. sp. An. Fac. Med. Univ. Recife, 15, 197.

Booker, D. V., Chamberlain, A. C., Rundo, J., Muir, D. C. F., and Thomson, M. L. (1967). Elimination of $5 \mu$ particles from the human lung. Nature (Lond.), 215, 30.

Brown, J. H., Cook, K. M., Ney, F. G., and Hatch, T. (1950). Influence of particle size upon the retention of particulate matter in the human lung. Amer. J. publ. Hlth, 40, 450.

Bukhari, A. Q. S. (1967). Studies on the passive sensitization of human lung. Ph.D. thesis, Edinburgh University.

Dickie, H. A., and Rankin, J. (1958). Farmer's lung: an acute granulomatous interstitial pneumonitis occurring in agricultural workers. J. Amer. med. Ass., 167, 1069.

Emanuel, D. A., Wenzel, F. J., and Lawton, B. R. (1966). Pneumonitis due to Cryptostroma corticale (maple-bark disease). New Engl. J. Med., 274, 1413. 
Filip, B., and Barbořík, M. (1966). Bronchopulmonální aspergilóza. Pracov Lék., 18, 6.

Findeisen, W. (1935). Uber das Absetzen kleiner, in der Luft suspendierter Teilchen in der menschlichen Lunge bei der Atmung. Pflügers Arch. ges. Physiol., 236, 367.

Forgacs, J., Carll, W. T., Herring, A. S., and Mahlandt, B. G. (1954). A toxic Aspergillus clavatus isolated from feed pellets. Amer. J. Hyg., 60, 15.

Frank, R. C. (1958). Farmer's lung-a form of pneumoconiosis due to organic dusts. Amer. J. Roentgenol., 79, 189.

Gell, P. G. H., and Coombs, R. R. A. (1963). Clinical Aspects of Immunology. Blackwell, Oxford.

Gregory, P. H., and Lacey, M. E. (1963). Mycological examination of dust from mouldy hay associated with farmer's lung disease. J. gen. Microbiol., 30, 75 .

Hargreave, F. E., Pepys, J., Longbottom, J. L., and Wraith, D. G. (1966). Bird breeder's (fancier's) lung. Lancet, 1, 445.

Longbottom, J. L., and Pepys, J. (1964). Pulmonary aspergillosis: diagnostic and immunological significance of antigens and C-substance in Aspergillus fumigatus. J. Path. Bact., 88, 141

Lunn, J. A., and Hughes, D. T. D. (1967). Pulmonary hypersensitivity to the grain weevil. Brit. J. industr. Med., 24, 158.

Mahon, W. E., Scott, D. J., Ansell, G., Manson, C. L., and Fraser, R. (1967). Hypersensitivity to pituitary snuff with miliary shadowing in the lungs. Thorax, $22,13$.

Ouchterlony, ర. (1949). Antigen-antibody reactions in gels. Arkiv. Kemi. Mineral. Geol., 26B, no. 14, pp. 1-9.

Pepys, J. (1967a). Conferences and meetings-thoracic medicine. Brit. med. J., $3,43$.

- (1967b). Leading article, Ibid., 1, 713.
— Jenkins, P. A., Festenstein, G. N., Gregory, P. H., Lacey, M. E and Skinner, F. A. (1963). Farmer's lung - thermophilic actinos mycetes as a source of 'farmer's lung hay' antigen. Lancet, 2, 607 Lachmann, P. J., and Mahon, W. E. (1966). An iatrogen autoantibody: immunological responses to 'pituitary snuff' in patients with diabetes insipidus. Clin. exp. Immunol., 1, 377. - Longbottom, J. L., and Jenkins, P. A. (1964). Vegetable dus

- Riddell, R. W., Citron, K. M., and Clayton, Y. M. (1962 Precipitins against extracts of hay and moulds in the serum ob patients with farmer's lung, aspergillosis, asthma, and sarcoidosis. patients with farme

Raper, K. B., and Fennell, D. I. (1965). The Genus Aspergillus. Williams and Wilkins, Baltimore.

Reed, C. E., Sosman, A., and Barbee, R. A. (1965). Pigeon breeder鵋 lung. J. Amer. med. Ass., 193, 261.

Riddell, R. W., and Stewart, G. T. (1958). Fungous Diseases an Their Treatment. Butterworth, London.

Salvaggio, J. E., Buechner, H. A., Seabury, J. H., and Arquembourso P. (1966). Bagassosis: i. Precipitins against extracts of crude bagasse in the serum of patients. Ann. intern. Med., 64, 748.

Seal, R. M. E., Thomas, G. O., and Griffiths, J. J. (1963). Farmer S lung. Proc. roy. Soc. Med., 56, 271.

Totten, R. S., Reid, D. H. S., Davis, H. D., and Moran, T. J. (1958 Farmer's lung-report of two cases in which lung biopsies were performed. Amer. J. Med., 25, 803.

Turner-Warwick, M., and Pepys, J. (1967). Some aspects of immune pathology and lung disease. Brit. J. Dis. Chest, 61, 113.

Wenzel, F. J., Emanuel, D. A., Lawton, B. R., and Magnin, G. E (1964). Isolation of the causative agent of farmer's lung. Ann. Allergy, 22, 533. 